University of Michigan Law School

University of Michigan Law School Scholarship Repository

1994

\title{
Character Impeachment Evidence: The Asymmetrical Interaction between Personality and Situation
}

\author{
Richard D. Friedman \\ University of Michigan Law School, rdfrdman@umich.edu
}

Available at: https://repository.law.umich.edu/articles/171

Follow this and additional works at: https://repository.law.umich.edu/articles

Part of the Criminal Procedure Commons, and the Evidence Commons

\section{Recommended Citation}

Friedman, Richard D. "Character Impeachment Evidence: The Asymmetrical Interaction between Personality and Situation." Duke L. J. 43, no. 4 (1994): 816-33.

This Article is brought to you for free and open access by the Faculty Scholarship at University of Michigan Law School Scholarship Repository. It has been accepted for inclusion in Articles by an authorized administrator of University of Michigan Law School Scholarship Repository. For more information, please contact mlaw.repository@umich.edu. 


\title{
COMMENTS
}

\section{CHARACTER IMPEACHMENT EVIDENCE: THE ASYMMETRICAL INTERACTION BETWEEN PERSONALITY AND SITUATION}

\author{
RICHARD D. FRIEDMAN $\dagger$
}

INTRODUCTION

In an interesting and useful Essay in the Duke Law Journal on character impeachınent evidence, Professor $\mathrm{H}$. Richard Uviller commented on iny own Article on the subject. ${ }^{1}$ Because I am flattered by the attention, I am not particularly upset by iny failure to persuade Professor Uviller, nor by his apparent failure to understand my argument. I do wish, however, that he had not misstated my arguinent im such a way as to render it stupid and inake me appear ignorant of what that learned barrister Horace Rumpole calls "the golden thread" of common law criminal jurisprudence-the presumption of innocence. ${ }^{2}$

Ironically, I believe that Professor Uviller does not disagree with the principal conclusion of my Article-that character impeachment evidence of criminal defendants ought to be excluded. Moreover, although he comments sarcastically on the analytical approach iny Article takes, I suspect that, if he focused more closely on it, he might find it more palatable than he recognizes because the key elements of my approach may be found in his own Article.

$\dagger$ Professor of Law, University of Michigan Law School.

1. See H. Richard Uviller, Credence, Character, and the Rules of Evidence: Seeing Through the Liar's Tale, 42 DUKE L.J. 776, 829-30 (1993) (commenting on Richard D. Friedman, Character Impeachment Evidence: Psycho-Bayesian [I?] Analysis and a Proposed Overhaul, 38 UCLA L. REV. 637 (1991)).

2. See JOHN MORTMMER, Rumpole and the Golden Thread, in RUMPOLE AND THE GOLDEN THREAD 55, 91 (1983). 
Concededly, my approach is one that many people, at least initially, find unattractive. Indeed, when I explained the arguinent of iny earhier Article to my wife, Joanna, she said, "I hate the way your mind works." I duly noted this assessment in an acknowledgment footnote to the Article, and Professor Uviller now hines up on her side, saying, "I can see her point." 3 Ouch-but if the wound is not self-inflicted, at least I suppose I left inyself open for it. I am glad to report that our marriage has been happy and productive. ${ }^{4}$ But my continued efforts at persuasion have had only limited success. "More than ever," Joanna says, she "hate[s] the way [my] mind works." Nevertheless, she says she has "become persuaded that for soineone whose inind works in that way [I have] a point." Well, that's the best I can do. I suspect that, without the considerable assistance of love and loyalty, I will find it even harder to convince Professor Uviller. But let me try.

In Part I of this Comment, I present a short version of my argument against the admissibihty of character impeachment evidence of criminal defendants, showing how the key elements of this argument are present in Professor Uviller's own Article. In Part II, I suggest that, notwithstanding Professor Uviller's comments to the contrary, an asymmetrical result-never admitting character evidence to impeach criminal defendants but admitting such evidence im some circumstances to impeach other witnesses-is perfectly reasonable. Finally, in Part III, I contend that Professor Uviller's interesting judicial surveys support the solution I have proposed for the problem of character impeachment evidence.

3. Uviller, supra note 1 , at 829 (citing Friedman, supra note 1 , at $637 \mathrm{n}^{*}$ ).

4. See Birth Certificate of Rebecca Abigail Friedman, born December 29, 1992 (on file in the Office of the County Clerk, Washtenaw County, Michigan).

5. Letter from Joanna Friedman to H. Richard Uviller 1 (Jan. 16, 1994) (on file with author and with the Duke Law Joumal) (emphasis added). The full text of the letter is as follows:

Dear Professor Ùviller:

I have given my husband numerous hours to convince me of the merits of his argument. Although I participated in these discussions willingly (at times initiating them), I found them to be excruciating. More than ever, I hate the way his mind works. Nonetheless, I have become persuaded that for someone whose mind works in that way-he has a point. My best wishes for a happy New Year.

Sincerely,

Id.

Joanna Friedman 


\section{Character IMPEACHMENT EVIDENCE OF CRIMINAL DEFENDANTS SHOULD BE EXCLUDED}

I have rather whimsically labelled the approach I have used to analyze character impeachment evidence as "psycho-Bayesian." The first part of this label is easy enough to understand: in determining the probative value of character impeachment evidence, the most important information is the nature of the psychological considerations leading people either to tell the truth or to he in a given situation. Inevitably, Professor Uviller, hike me, draws conclusions about the psychology of truth tellimg and lying. ${ }^{6}$ As to the second part of the label, analysis of the probative value of evidence inevitably involves analysis of probability: the probative value of evidence with respect to a proposition is the impact of that evidence on the probability of the proposition.? Again mevitably, Professor Uviller speaks in terms of probabilities; indeed, at one point, he exphicitly combimes psychological and probabilistic analyses. ${ }^{8}$ Bayesian logic, which he does not use, helps to make probabilistic analysis more rigorous and precise. ${ }^{9}$

Although Professor Uviller refers to me as a "formula probabilist, ${ }^{, 10}$ there is notling formulaic, or numerical, or even particularly complicated about the Bayesian analysis needed for a basic understanding of character impeachment evidence. ${ }^{11}$ The essential msight of Bayesian analysis for these purposes is that, in evaluating the probability of a given proposition to which a wit-

6. See infra note 8.

7. See FED. R. EVID. 401 (“'Relevant evidence' means evidence having any tendency to make the existence of any fact that is of consequence to the determination of the action more probable or less probable than it would be without the evidence.").

8. Professor Uviller argues,

[B]y the laws of personality and behavior, either [of two street muggers] is substantially more likely to have committed the mugging in question than a person drawn at random from those who have never committed a robbery. And the more probably guilty person (viz., the one with the record) who gives exculpatory testimony is more likely to be lying than is a more likely innocent person, simce truthful testimony will help acquit the innocent but will surely convict the guilty.

Uviller, supra note 1 , at 815 .

9. See infra notes 12,16 (analyzing the elements of witness credibility and showing how its relation to uuderlying substantive issues can be clarified).

10. Uviller, supra note 1 , at 830 .

11. In an Appendix to my earlier Article, I did present two diagrams and some simple mathematical probabilistic analysis, but these were by no means essential to the argument. See Friedman, supra note 1, at 692-97. 
ness has testified, the jury must in essence assess three more elemental probabilities:

1. The probability of the proposition as assessed without regard to the testimony.

2. The probability that the witness would give this testimony if the proposition were true.

3. The probability that the witness would give this testimony if the proposition were not true.

The greater the first probability, all other things being equal, the more probable is the proposition, given that the witness has testified to it. This first probability assessinent, however, has nothing to do with the witness's credibility as such because the assessment is nade without regard to the witness's testimony. The witness's credibility is dependent on the second and third probabilities: the greater the ratio of the second to the third probability, the more credible the witness is with respect to the proposition at issue. ${ }^{12}$ (I thus find inystifying Professor Uviller's critique that $I$ ignore or assume out of iny equations the critical factor of witness credibility ${ }^{13}$ like him, my focus is on credibihty, which $\mathrm{I}$ break down into coinponents for greater analytical rigor.).

To avoid misunderstanding, I should carefully confine the nature of my claim. I certainly do not contend that a jury should assign numerical values to each of these three probabilities. Nor, for that inatter, do I mean that the jury does, or even necessarily should, expressly assess each of these probabilities in turn. My contention is more modest: The jury's assessment of the probability of the proposition, in hight of the testimony, should be consis-

12. I have previously distinguished between the personal credibility of the witness in making a statement and the credibility of the statement itself. See Richard D. Friedman, Route Analysis of Credibility and Hearsay, 96 YALE L.J. 667, 678 (1987). The former depends on the ratio of the second and tlird probabilities, which $I$ have called the credibility ratio of the witness im making the statement. Id. at 677 . The latter is merely the probability tliat the proposition to which the witness has testified is true given all the evidence, including the witness's testimony. This probability depends on all three of the more elemental probabilities, as described in the text; obviously, the credibility of the witness has significant bearing on the credibility of the statement.

I believe this distinction helps an analyst not only to focus on the elements of the witness's credibility but also to clarify the relation between the issue of witness credibility and substantive issues. See infra note 16 (discussing an argument presented, but ultimately rejected, by Professor Uviller, which combimes the question of witness credibility with the underlying substantive issue).

13. See Uviller, supra note 1 , at 830 . 
tent with the assessments that it would make-if it did make such assessments-of the three more elemental probabilities. This contention leads to an important corollary: To assess the value of a piece of evidence bearing on the credibility of a witness, one may assess the bearing that the evidence has on each of these three probabilities.

This perspective thus provides the framework for a careful analysis of the probative value of character impeachment evidence. The impact of character impeachment evidence on the jury's determination of the probability of a material proposition depends on the impact of the character impeachment evidence on each of these three probabilities. I will concentrate here on the most important case, character impeachment of a criminal defendant who presents exculpatory testimony in his own defense. As limited to this purpose, the three elemental probabilities may be stated more particularly:

1. The probability of innocence as assessed without regard to the defendant's testimony.

2. The probability that the defendant would testify as he has assuming the testimony is true-that is, assuming he is innocent.

3. The probability that the defendant would testify as he has assuming the testimony is false-that is, assuming he is guilty. ${ }^{14}$

Now, let us examine in turn how character impeachment evidence may affect the jury's assessment of each of these three probabilities.

14. I am simplifying somewhat, equating the truthfulness of the defendant's exculpatory testimony with his innocence and the falsity of that testimony with his guilt. This equation does not hold completely. As Professor Uviller points out, even innocent defendants "will lie or omit facts where the full truth would heighten suspicion." Uviller, supra note 1 , at 813 . Correspondingly, even a guilty defendant who testifies will presumably tell the truth about some facts that do not appear to heighten suspicion.

Nevertheless, the simplification is a valid one to make. For one thing, on the crucial propositions-the ones central to the case-the equation will ordinarily hold: if the defendant's exculpatory story is true, he is innocent, and if he is innocent, his exculpatory story is presumably true, at least in its most important aspects, whereas if the defendant is guilty, his exculpatory story must be false, and if that story is false, he is probably guilty. Furthermore, a persuasive case for admitting character impeachment evidence against a criminal defendant camot be based on the value that the evidence has in impeaching an innocent defendant, or in impeaching a guilty defendant with respect to the peripheral aspects of his testimony that happen to be true. 


\section{A. The First Probability Assessment}

If evidence of a prior crime is introduced merely to impeach a witness's character for truthfulness, it can have no legitimate effect on the first probability. As suggested above, the first probability assessment has nothing to do with how the jury should assess the witness's credibility; it is an assessment of the probability of the proposition in question-here, the witness-defendant's innocence-as assessed without the defendant's testimony.

Even if properly instructed, however, a jury will likely use character impeachinent evidence improperly to affect its assessment of the first probability. ${ }^{15}$ For example, it may think,

Whether or not this prior crime bears on the likelihood that the accused would tell the truth in this case, it certainly makes it more likely that he committed the crime with which he is charged here. After all, one who commits one crime is more likely to commit another.

Reasoning of this sort, as Professor Uviller exphicitly recognizes, "accord[s] with logic and experience."16 As he further asserts, however, such reasoning is also "utterly repugnant" to other pre-

15. See Roselle L. Wissler \& Michael J. Saks, On the Inefficacy of Limiting Instructions: When Jurors Use Prior Conviction Evidence to Decide on Guilt, 9 LAW \& HUM. BEHAV. 37, 47 (1985) (concluding that the presentation of a criminal record increases the likehhood that the defendant will be convicted, despite the judge's himiting instructions).

16. Uviller, supra note 1, at 815 . Compressing substantially, Professor Uviller presents the reasoning as follows:

[A] person who has previously committed a certain type of crime is more likely [than another] to have committed [the mugging charged] .... Thus, testifying criminal defendants with records, especially for the same sort of crime, are more likely to be lying on the stand than those without records, because they Id. are more likely to be guilty.

This argument combines the questions of the witness's credibility and the underlying substantive proposition-here, guilt or innocence-as evaluated in light of all the evidence, including the witness's testimony. See supra note 12 (drawing the distinction between the personal credibility of the witness in making the statement and the credibility of the statement itself). Note, however, that, in this reasoning, the proposition of witness veracity is an inference, perhaps gratuitous, from, not a premise of, the inference of guilt. Clearly, the essential reasoming is the same as the reasoning represented in the hypothetical quotation in text-that is, that the prior crime makes it more likely, on propensity grounds, that the accused committed the crime in question. Witness veracity plays no part in this inference. See also Uviller, supra note 1, at 813 (arguing that evidence of criminal conduct more readily supports an inference of primary conduct than an inference of a predisposition to he under oath). 
mises of our trial system. ${ }^{17}$ The difficulty is the policy decision underlying rules like Federal Rule of Evidence 404 that, in general, we do not want factfinders to use the accused's propensity to do wrong as a basis for finding that the accused committed the crime in question. ${ }^{18}$ That policy has been challenged (although not by me). ${ }^{19}$ While it is in force, character evidence impeachment must be considered prejudicial to the extent that the jury does use it to conclude that the accused had a propensity to commit the crime charged.

\section{B. The Second Probability Assessment}

The second probability assessment requires the jury to determine how likely it is that the accused would testify as he has assuming the proposition to which he has testified is true. Given that the testimony is exculpatory, that probability is presumably very high. This observation is no less true when the accused is a person of relatively poor credibility: even if the accused is perfectly willing to lie im his self-interest, lie will presumably be willing to tell the trutli if doing so serves his interest. Once more, Professor Uviller agrees; as lie puts it, "Innocent defendants in criminal cases will of course tell the truth imsofar as it promotes acquittal." ${ }^{20}$ Character impeachment evidence therefore will have no substantial bearing on the second probability assessment.

17. Uviller, supra note 1 , at 815 .

18. There are exceptions to this general principle. See, e.g., FED. R. Evid. 404(a)(1), (2). Moreover, this principle does not preclude admissibility of a witness's, including a criminal defendant's, prior bad acts for substantive (i.e., non-credibility) purposes other than showing the witness's propensities. For example, if the theory of the prosecution is that the accused committed murder to cover up a robbery, the prosecution ordinarily ought to be allowed to prove the robbery to show a motive for committing the murder. See FED. R. EVID. 405(b). My proposal that the use of character impeachment evidence of criminal defendants ought to be eliminated would not alter the rules bearing on these other uses of prior conduct.

19. See Office of Legal Policy, U.S. Dep'T of Justice, Truth in Criminal JUSTICE SERIES, REPORT NO. 4, REPORT TO THE ATTORNEY GENERAL ON THE ADMISSION OF CRIMINAL HISTORIES AT TRIAL (1986), reprinted in 22 U. MICH. J.L. REF. 707, 710 (1989).

20. Uviller, supra note 1 , at 813 ; see supra note 14 (discussing the possibility that an innocent defendant may provide some false testimony). 


\section{The Third Probability Assessment}

By process of elimination, then, if the case for character impeachment evidence of a criminal defendant is to be made, it must be based on the impact of that evidence on the third probability assessment. That assessment is of the probability, assuming hypothetically that the defendant is guilty, that he would give exculpatory testimony. Careful analysis shows, however, that character impeachment evidence will have no substantial value with respect to this probability assessment.

The prosecution will be eager to show that the third probability is very high-that is, that, assuming hypothetically that the defendant is guilty, he would very likely testify as he has. For the defendant to testify as he has, he must have been not only able to testify in that way but also willing to perjure himself. With respect to the defendant's ability to bring the lie off, character impeachinent evidence-essentially showing that the defendant has been caught doing bad things before-will not help the prosecution. ${ }^{21}$ The question, then, coines down to whether character impeachment evidence will help substantially in showing that the defendant is willing to inake an exculpatory statement under oath.

I beheve the answer is clearly negative, for two reasons. First, and more obvious, is that perjuring himself is overwhelmingly in the defendant's interest. Professor Uviller puts the point well:

All guilty defendants who choose to testify will lie on the stand about anything that might improve their chances and about which they miagine they can be persuasive. For virtually all-novice and experienced criminal-acquittal is the overriding, intensely desired, goal, and the risks of perjury are inmimal. ${ }^{22}$

Second, by the hypothesis governing this probability assessinent, the defendant is guilty of a crime-the one charged. Evidence of other misconduct tending to show bad character will therefore tend to be cumulative. ${ }^{23}$

It is this last argument that particularly draws Professor Uviller's attempt at withering sarcasm. He says that I contend that character impeachment evidence of a criminal defendant will be overkill, in part because of "the jury's assumption that he is guilty

\footnotetext{
21. Friedman, supra note 1, at 664-66.

22. Uviller, supra note 1 , at 813 .

23. See Friedman, supra note 1 , at 660-63.
} 
of the crime charged."24 "Who can quarrel," he then asks, with the "thesis that where the jury is operating on the assumption that the accused is guilty, the prosecution need not resort to an attack on credibility through evidence of bad character?"25

Yes, I am aware of-and applaud-the presumption of innocence. Of course, I never suggested that the jury would, or should, assume that the defendant is guilty, $m$ the sense of approaching the case with a presumption of guilt. Rather, my argument is that, if the jury's task is broken down analytically, one part of that task-the critical part for assessing the value of character impeachment evidence-involves the hypothesis that the defendant is guilty. I think I was clear on this point; I certainly was explicit. ${ }^{26}$

Iromically, Professor Uviller seems quite clearly to take the same approach, focusing on the likelihood that the defendant would hie, assuming he is guilty. Just before analyzing "the disposition to he under oath," ${ }^{27}$ he declares his belief that

murderers are [no] more inclined to try to obtain their acquittal by lying than are street-level dope pushers.... [T] accused of the lesser offense shares to the fullest the murderer's fervent desire for acquittal, just as both share fully the desire of the counterfeiter to procure his release by perjury if necessary and possible. ${ }^{28}$

This passage bears some resemblance to one I have used to crystallize my basic argument. In my view, character impeachment evidence caimot substantially alter a rational juror's assessment of a criminal defendant's mclination to lie unless the juror follows a train of thought something like the following: "At first I thought it was very unlikely that, if Defoe committed robbery, he would be willing to he about it. But now that I know he committed forgery

24. Uviller, supra note 1 , at 830.

25. Id.

26. In my Article, I noted that the third probability assessment

might appear to conflict with the presumption of innocence, but it does not; that presumption is satisfied if the jury is instructed, im effect, to begin with a very low assessment of the first probability [it would have been better to say, "a very low assessment of the probability of guilt"], before the prosecution has introduced any evidence.

Friedman, supra note 1, at 658; see also id. at 660 (referring to "the hypothesis of the question"); id. at 661 (referring to "what the jury is already assuming hypothetically").

27. Uviller, supra note 1 , at 813.

28. Id. at 812 . 
a year before, that possibility seems substantially more likely."29 It seems plain, however, that it is highly improbable that a rational juror would follow such a train of thought. ${ }^{30}$ From what he has said, it certainly seems that Professor Uviller agrees.

Thus far, I have argued that character impeachment evidence has insignificant probative value im impeaching the credibility of a criminal defendant who takes the stand and that this evidence often has great prejudicial potential, in that the jury might rationally use it to inake the forbidden inference of propensity to coinmit the crime. Alternatively, the defendant may avoid this prejudice by staying off the stand-but then the threat of the character impeachment evidence will have forced the defendant to waive the fundamental constitutional right to testify and possibly will have deprived the truth-determining process of valuable information. ${ }^{31}$ Taking all these factors into account, it clearly seems appropriate to adopt a simple rule against character impeachment evidence of a criminal defendant.

Although he follows a different analytical path, Professor Uviller appears to agree with this conclusion. Indeed, he goes much further, expressing grave doubts about the value of character impeachment evidence with respect to any witness. ${ }^{32}$ By contrast, I beheve that im some situations, character impeachment evidence inay be net beneficial.

\section{THE CASE FOR AN ASYMMETRICÁl SOLUTION}

The argument I have inade for the exclusion of character impeachment evidence of criminal defendants is based in part on the perception that, in analysis of the willingness of a hypothetically guilty criminal defendant to perjure himself in his defense, situational factors overwhelm personal factors. That is, the critical fact is that the defendant is in a situation creating an extremely powerful incentive to he. ${ }^{33}$ Given that fact, we do not need to know

29. Friedman, supra note 1 , at 637.

30. Id. at $637,663-64$.

31. Moreover, in jurisdictions following the rule of Luce v. United States, 469 U.S. 38 (1984), if the threat of character inpeachment evidence scares the defendant from taking the stand, he does not preserve for appellate review objections he may have to the admissibility of that evidence.

32. See Uviller, supra note 1 , at $830-31$.

33. I have peeked ahead to Professor Uviller's reply to this Comment, see H. Richard Uviller, Unconvinced, Unreconstructed, and Unrepentant: A Reply to Professor 
Friedman's Response, 43 DUKE L.J. 834, 837-38 (1994), and acknowledge that he has caught me in an unfortunate and careless ambiguity-but one that $I$ have now corrected by inserting the words "hypothetically guilty" in the prior sentence of the text. These words reflect, rather than alter, what I mean to say, which may be apparent from their context; indeed, before reading Professor Uviller's reply, I had already used comparable language later in this paragraph of the text.

I do not mean to be making the assertion, which would be incorrect, that all criminal defendant have "an extremely powerful incentive to lie." Obviously, that is not true of innocent defendants-who, as both Professor Uviller and I have pointed out, see id. at $839-40$, have a strong incentive to tell the truth.

Nor, contrary to Professor Uviller's implication, see id. at $840-41$, do I mean to be operating on the premise that most criminal defendants are guilty, so that the defendant in this case is probably guilty. That may be true, but it is irrelevant to my argument, and I agree absolutely that it would be wrong to make decisions in the particular case depend upon the perception-whether accurate or not-that most defendants are guilty.

Nor do I "choose[] a defendant and assume[] that the defendant is guilty and therefore highly hikely to lie." Id. at 837-38. Regrettably, it appears to me that Professor Uviller continues to misunderstand my analysis. See also id. at 840 (apparently attempting to apply, but imstead mangling, my analysis, by speaking of the possibility that "the jury will tend to put the accused in the 'third category' (that is, consider him guilty)"). That analysis contends that the factflnder's task in determining whether or not the defendant is guilty involves in part operating in turu on each of two inconsistent hypotheses-first, that the defendant is innocent, and second, that the defendant is guilty-and asking on the basis of each hypothesis how likely it is that the defendant would testify as he has.

Granted, my principal focus is on the second of these hypotheses, and thus on what I have called the third probability assessment, because the analysis indicates that, if-assuming not ouly hypothetically but, to my mind, counterfactually-character evidence has significant value in impeaching a criminal defendant, it could only be because that evidence has a substantial impact on the factfinder's assessment of the third probability. I believe that the evidence clearly will not have such an impact, at least if the factfinder is thinking rationally. Ironically, Professor Uviller not only agrees but thinks that the evidence "[o]bviously" has no sucl impact: "Even careless analysis should inform us that a guilty defendant is very likely to give exculpatory testimony if he clooses to testify-regardless of his cliaracter." Id. at 838. But if the character evidence does not show that the defendant is substantially more likely to lie if lie is in fact guilty, then what possible value does it have in impeaching the defendant?

I think part of the reason for Professor Uviller's continued misunderstanding of my argument may be that he misunderstands the concept of probability used in the argument. He believes that the concept of probability that he is accustomed to using-"to express the degree of certainty I feel that an event did or did not happen"-is different from the concept that a "logical probabilist" would use, that the latter concept depends on "numerical data," and that only with sucl data can a "formal computation" of probability be made. Id. at 836. In fact, Professor Uviller's own idea of probability expresses quite well the concept of probability that $I$ am using-as a measure of the subjective degree of belief that an observer lias in a given proposition-and that is the standard concept used by subjective probabilists. See, e.g., BRUNO DE FINETTI, THEORY OF PROBABILITY (1975). Even when the observer is given numerical data bearing on a proposition, a subjectivist regards the probability as subjective; it is a subjective matter, for example, how to assess the reliability of the data. But, if the observer is thinking rationally, lier probability assessments, even if they lack any nnmerical basis, should be consistent with eacl other in conformity with probability theory. Suppose, for example, that 
very much about the defendant personally to reach the reasonable conclusion that there is a high probability that the defendant will be willing to he. Moreover, $m$ analyzing the crucial question of how likely it is that the defendant, if guilty, would be willing to he, we are already assuming hypothetically an important fact about the defendant personally: that he is guilty of the crime charged. That hypothetical fact at least suggests that the defendant is not one of those unfortunately rare people so self-abnegatory that he will not he, even if able to do so convincingly, to escape criminal pumishment.

Now compare the case of a witness who has a long-standing grudge against a criminal defendant and who testifies for the prosecution about an event that she observed but in which she did not participate. The situational factors are not so strong: inany people would be willing to perjure themselves in this situation, and many would not. The hypothesis of the crucial probability assessment-how probable is it that, if the facts were not as the witness has testified, she would nevertheless give the testimony she has-does not help; it tells us nothing, even hypothetically, about the witness's personality or character or inclination to tell the truth. ${ }^{34}$ In such a case, it may be helpful for the jury to have information bearing on the witness's character for truthfulness. Moreover, the disadvantages of character impeachment evidence are far less significant in this situation than when the witness is a criminal defendant. ${ }^{35}$

the observer assesses the probability that it will rain tomorrow as .4 and the probability that if it rains tomorrow the picnic will be cancelled as .7; she should not then assess the probability that the picnic will be cancelled as .1 .

I believe, however, that the reasons for Professor Uviller's continued misunderstanding of my argument go beyond narrow failure to recognize the concept of probability that I am using. I believe my wife was on to something when she pointed to the different ways our minds work. As anyone who has debated with Joanna can attest, her mind works not only quickly and powerfully but also with great analytical rigor. And yet, hike Professor Uviller-like many people of great intelligence-she finds the type of analysis presented here extremely unappealing and difficult to accept. The easy explanation may appear to be that the analysis is faulty. Naturally, I shudder at the thought. I am fortified by the realization that many other people-at least some of whom happen to be quite intelligent-find Bayesian analysis to be not only appealing but also sensible and very useful for some analytical tasks. So I will just accept that there is a great intellectual divide and leave to Joanna and her fellow psychologists the question of why this divide exists and persists.

34. In his Comment, Professor Uviller quotes this statement out of context, giving it a meaning that I do not intend. See Uviller, supra note 33, at 839.

35. First, the danger that the jury will use the character impeachment evidence for 
There remains the danger, which Professor Uviller emphasizes, that the jury will place too much emphasis on the character impeachment evidence. ${ }^{36}$ Nevertheless, I beheve that in a case hike this one, and various other situations as well, some character impeachment evidence may do more good than harm; if there is evidence strongly suggesting that the witness is a person who, with relative alacrity, would ignore her social obligation to tell the truth imder oath, that information may well be net beneficial to the truth-determining process.

I have not attempted to articulate a rule that would prescribe in detail when a witness (other than a criminal defendant) ought to be subject to character impeachment evidence. For now, at least, I prefer to resort to the haven used by Federal Rule of Evidence 608 (and often used by those unable to articulate a rule prescriptive in detail)-leaving the matter to the discretion of the court, subject to appropriate review, in the particular case. ${ }^{37}$

Professor Uviller fears leaving the matter to judicial discretion, ${ }^{38}$ but discretion need not be unguided. In my view, various factors ought to determine whether a particular witness (other than a criminal defendant) should be subject to impeachment by particular character evidence. Among these are whether the witness is a party, or at least has a strong affiliation with a party; whether the witness's testimony is offered to deny a charge that her own conduct is wrongful; whether the witness's conduct before taking the stand in particular is in issue at all; whether the party who put the

an improper purpose, i.e., to draw conclusions about the witness's non-testimonial propensities, is not great. Because the witness is only an observer, her non-testimonial propensities are not material and are unlikely to affect the jury's result. Second, the difficulty of burdeming a criminal defendant's right to testify in his own defense does not arise. The threat of character impeachment evidence may still keep the witness off the stand (most likely because the prosecution, which would be the proponent of her testimony, decides that if the defense effectively impeaclues luer cluaracter her testimony will not be net beneficial), but this result is less likely than in the case of the criminal defendant and, in any event, less worrisome.

36. See Uviller, supra note 1 , at 830 . Note that, contrary to Professor Uviller's rather unaccountable suggestion, Uviller, supra note 33 , at $841-42$, I do not contend that a criminal defendant is the only party who slould be able to claim that character impeachment evidence is prejudicial. I do believe that the prejudice tends to be most probable, and most problematic, when the witness being impeacled is the criminal defendant. Clearly, however, the possibility of prejudice must be considered whenever character impeaclument evidence is offered.

37. See FED. R. EVID. 608.

38. See Uviller, supra note 1 , at 829 . 
witness on the stand is a criminal defendant; and how strongly the character impeachment evidence indicates dishonesty. ${ }^{39}$

When all is said and done, I would leave open the possibility that a criminal defendant would be allowed in a particular case to impeach a prosecution witness with character evidence, even though I also would bar the prosecution from introducing such evidence to impeach the defendant should he take the stand. This proposed solution arouses Professor Uviller's scorn. He calls it "a politically correct but otherwise unimpressive idea." 40 Well, I suppose at least that is an improvement over the assessinent of one of iny colleagues that I am "politically incorrect and otherwise unimpressive."

Evidently, what draws Professor Uviller's charge of political correctness is his perception that my left knee jerks in favor of criminal defendants. ${ }^{41}$ It seems to me I should be rendered immune to that charge because of a corollary I have offered to my argument that character impeachment of criminal defendants should be uniformly excluded. I have suggested that if that arguinent were adopted, there would be a good basis for reexamining the rule of Griffin v. California ${ }^{42}$ that a prosecutor is barred from conımenting on an accused's failure to testify. ${ }^{43}$ Abrogation of this rule, plainly, would be a great benefit to prosecutors.

39. For a discussion of these factors in greater detail, see Friedman, supra note 1, at 684-85.

40. Uviller, supra note 1 , at 829 . Professor Uviller says that I believe that "all criminal defendants should be relieved of any bad acts, ill-repute, or criminal convictions in their past, and be allowed to testify as pure lambs while sullied prosecution witnesses should take the stand at the mercy of judicial discretion." Id. (citing Friedman, supra note 1 , at 689-90). I think this characterization is rather misleading. The defendant will not appear as a "pure lamb" to the jury. The jury will hear the prosecution's evidence tending to prove that the defeudant committed the crime charged and, as I have argued, it will assume hypothetically for purposes of the key question bearing on credibility that he has indeed committed that crime. By contrast, if character impeachment evidence of prosecution witnesses is not allowed, it may be that a prosecution wituess falsely appears as a "pure lamb." Furthermore, my present concern is not with all character evidence but only with character impeachment evidence. Although I would eliminate use of character evidence offered to impeach the defendant's credibility, I do not advocate "relieving" criminal defendants of all bad acts in their pasts; I do not propose altering the rules bearing on other uses of a defendant's prior bad acts. See supra note 18.

41. If, however, it jerks no less strongly in favor of the defendant when the charge is sexual assault or misconduct, then I doubt that I would now be considered politically correct.

42. 380 U.S. 609 (1965).

43. Friedman, supra note 1, at 678-80; see Griffin, 380 U.S. at 615. 
Nevertheless, my solution does treat criminal defendants and witnesses testifying agamst them asymmetrically with respect to character impeachment evidence itself. But so what? Our criminal justice system is full of asymmetries in favor of the accused. ${ }^{44}$ To take one example strongly resembling the one I propose, a defendant accused of assault and asserting self-defense may choose to put $m$ issue the character for violence of the alleged victim, but even if he does so, the prosecution may not place in issue the defendant's own character for violence. ${ }^{45}$ The existence of other asymmetries is not, of course, a sufficient argument to add one more. If the asymmetry makes sense, however, we should not shrink from it. ${ }^{46}$

If I am right that character impeachment evidence of a criminal defendant is always, or almost always, more prejudicial than probative and that sometimes character evidence impeaching a prosecution witness may be more probative than prejudicial, then this asymmetry does make sense; it simply responds to different situations with different results, each promoting the truth-determining process. Indeed, in some situations, an asymmetrical evidentiary rule may be considered corrective of an asymmetry inherent in the situation. The accused is simply in a different situation from any other potential witness-for either the prosecution or the defense-in a criminal case. (Note in this connection that I do not argue that there should be a per se rule against character impeachment evidence of defense witnesses.) The accused's conduct is necessarily the central issue in the case, and even without character impeachment evidence, the prosecution will do its best to put him im a bad light by trying to show that he committed the crime charged. If the prosecution witness is a mere observer, however,

44. See, e.g., Richard D. Friedman, An Asymmetrical Approach to the Problem of Peremptories?, 28 CRM. L. BULL. 507, 518 (1992) (presenting various asymmetries created by the judicial system).

45. See FED. R. EVID. 404(a)(1)-(2). If the defendant places in issue the character of either the alleged victim or himself, respectively, the prosecution may respond with evidence bearing on that person's character. Id.

46. Indeed, Professor Uviller thinks this point is "silly." Uviller, supra note 33, at 843. I think his view of it is silly. So there.

Obviously, I am not arguing, "We already have lots of asymmetries; who cares about another?" Rather, I am simply pointing out that asymmetrical solutions, even quite similar to the one I propose, are familiar and accepted. The asymmetry should not foreclose us from adopting such a solution if, as I argue is the case, sound considerations support a given rule with respect to the defendant and a different rule with respect to other witnesses. 
the defense may not have any comparable mudslinging opportunity-unless character impeachment evidence is allowed. ${ }^{47}$

In any event, the asymmetry would arise within a single case only if both the defendant and one or more prosecution witnesses would be subjected, the court permitting, to character impeachment evidence. If it were deemed necessary (which I do not think it is) to ehminate that asymmetry by rule, this result could be achieved in any number of various ways. ${ }^{48}$ Alternatively, the asymmetry might be considered a factor for the court to take imto account $\mathrm{m}$ exercising its discretion when deciding whether to admit character evidence impeaching a prosecution witness.

\section{SIMPLIFYING THE RULES}

The essence of my proposed overhaul of the rules concerning character impeachment is this: Character impeachment of criminal defendants should be eliminated, and all other character impeachment evidence, including proof of prior convictions, should be subject to a discretionary rule. In terms of the Federal Rules of Evidence, these changes could be accomphished quite simply. First, Rule 608, the discretionary rule that applies to all types of character mipeachment evidence except for prior convictions, should be expanded to apply to that type of evidence as well but narrowed to exclude character impeachment of criminal defendants. Second, Rule 609, which now prescribes in substantial detail situations in which the trial court must, may, and may not admit evidence of prior convictions, should be eliminated. ${ }^{49}$

These changes would vastly simplify the law of character impeachment; that in itself must be considered a great improvement. After taking two very interesting surveys of federal district judges

47. See generally supra note 35 and accompanying text.

48. Assuming a per se rule against character impeachment evidence-the result I regard as most important-the most restrictive way of eliminating the asymmetry would be to bar all character impeachment evidence in criminal cases. A less restrictive rule would bar character impeachment evidence of prosecution witnesses if the prosecution has available character evidence that, but for the per se exclusion, would be admissible to mipeach the accused. (Preferably, this rule would only be applied if the defendant actually testifies because only then would the asymmetry in treatment actually come into play.) A yet less restrictive (and therefore, to my mind, probably better) rule would give the accused a choice: he would have an opportunity to offer character evidence impeaching prosecution witnesses only if he either did not testify or waived his right to exclude the prosecution's offer of character evidence impeaching him.

49. For a draft of these proposed changes, see Friedman, supra note 1, at 689-90. 
to explore their attitudes and practices towards character impeachment, Professor Uviller fonnd particularly troublesome the "variety of judicial readings of the rules." ${ }^{50}$ Professor Uviller's questions concentrated on the apphication of Rule 609 and on the interplay between Rules 608 and 609 because that is where the complexity hes. Indeed, as his first survey strongly suggests, a great deal of confusion lies there as well. ${ }^{51}$ The 1990 amendment to Rule 609 does not seem to have reheved the problem. ${ }^{52}$

Eliminating Rule 609 would eliminate most of the complexity and confusion. This benefit is not a sufficient reason for the change, of course; sometimes complexity and confusion are the price of maintaming a body of law that reaches sound results most of the time. That is not the case here, however.

Consider first the situation, which accounts for the great bulk of the use of Rule 609, in which the proponent seeks to impeach a criminal defendant by prior conviction evidence. If admissibility of prior conviction evidence were often appropriate in this situation, then a highly prescriptive rule wonld probably be appropriate as well. The evidence is potentially so devastating to the defendant that it is probably appropriate to control the trial court more than most evidentiary rules do. The goals of benefitting the truth-determining process and removing a serious burden on the accused's right to testify in his own defense, however, are sufficient to justify a total exclusion of character impeachment evidence of criminal defendants. That such an exclusion also would eliminate most of the occasion for maintaining a complex and confusing body of law is an attractive side benefit.

Indeed, assuming that character impeachment evidence of criminal defendants is eliminated, there seems hittle point in maintaming a highly prescriptive rule such as Rule 609 to provide the standards for impeaching other witnesses by prior convictions. Prior conviction impeachment is not usually as potentially prejudicial when the witness is not a criminal defendant, nor is our concern over the level of prejudice as high. Moreover, the prescriptions of Rule 609 have httle in common with the factors that, I have argued, should guide decisionmaking in this area. ${ }^{53}$ On bal-

\footnotetext{
50. Uviller, supra note 1 , at 820 .

51. See id. at 817-24, 833-36.

52. Id. at $820,833,836$.

53. See supra text accompanying note 39 .
} 
ance, therefore, it seems preferable to accord trial judges a good deal of discretionary leeway, which they already have not only in most other areas of evidentiary law ${ }^{54}$ but also, under Rule 608, with respect to all other types of character impeachment evidence.

The system I propose, then, would eliminate the main source of complexity and confusion-the highly prescriptive Rule 609. It wonld narrow Rule 608 in one respect and broaden it another, leaving the flexibility of that rule imtact. I suspect that if the system were adopted and Professor Uviller took another survey, he would find much inore comforting levels of understanding.

Note also how criminal trials would be transformed. We would no longer deal with the charade of evidence supposedly offered to prove that the accused is unworthy of behef but actually having hittle value in the circuinstances to prove that proposition and really offered to show that the accused is a bad person with a propensity for criminal behavior. Nor would the prospect of such evidence scare the accused off the stand; not facing an overwhelming disincentive to testify, he would have an unobstructed opportunity to tell his side of the story under oath to a jury that could assess his testimony fully aware of his self-interest. And perhaps we also would candidly allow the jury to draw the natural inference that if the accused decides not to testify, it may be because he does not have a persuasive story to tell.

To me, that vision sounds a lot better than the system we have. I hope it will to Professor Uviller as well. I even have hopes of persuading my wife.

54. See, eg., FED. R. EVID. 403 (giving courts general discretion to exclude evidence substantially more prejudicial than probative); FED. R. EVID. 702 (giving courts broad discretion in determining admissibility of expert evidence); FED. R. EVID. 803(24), $804(b)(5)$ (allowing broad, discretionary, residual exceptions to the rule against hearsay). 